Agro-Science Journal of Tropical Agriculture, Food, Environment and Extension Volume 19 Number 3 (July 2020) pp. 8 - 14

ISSN 1119-7455

\title{
POTENTIALS FOR THE COMMERCIALIZATION OF COCOYAM IN OYUN LOCAL GOVERNMENT AREA, KWARA STATE, NIGERIA
}

\author{
*Omotesho K.F., Kayode A.O., Adebayo S.A., Akinrinde A.F. and Mohammed A.J. \\ Department of Agricultural Extension \& Rural Development, \\ University of Ilorin, PMB 1515 Ilorin, Nigeria
}

*Corresponding author’s e-mail: kfomotesho@gmail.com; omotesho.kf@unilorin.edu.ng

\begin{abstract}
Despite the nutritional and other advantages of cocoyam over some tuber crops, it remains neglected, underutilised, and non-commercialized in many parts of Nigeria. The study assessed the potentials for the commercialisation of cocoyam. Specifically, it assessed farmers' awareness of the uses of cocoyam, level of cocoyam cultivation, farmers' attitude towards its commercialisation, and the constraints to its commercialisation. Two-stage random sampling technique produced 154 respondents and an interview schedule was administered to collect data. Descriptive statistics and the multiple regression analysis were used for data analysis. Results revealed that farmers' mean age, farming experience and farm size were 53.9 years, 22 years, and 4.3 acres respectively. The level of awarenessof the uses of cocoyam was high (73.52\%) and had an averagely positive attitude (mean score $=2.38$ ) towards its commercialisation. Cultivation of cocoyam was mostly on a subsistence level among the farmers (97.3\%). High susceptibility to pests and diseases $(M S=3.13)$ and a higher preference for other tuber crops $(M S=3.09)$ were the major constraints to the commercialisation of cocoyam. Farmers' age $(\beta=-0.008)$, level of education $(\beta=-0.046)$, household size $(\beta=-0.012)$, and frequency of extension contact $(\beta=0.018)$ determined farmers' attitude towards its commercialisation. The study concluded that the potentials for the commercialization of cocoyam was appreciable in the study area. Findings underscore the need for research on cocoyam pest and diseases control as well as breeding of improved varieties of the plant by National Root Crops Research Institutes.
\end{abstract}

Key words: attitude, commercialization, neglected, under-utilized and cocoyam

\section{INTRODUCTION}

Issues such as ending world hunger, eradication of poverty, and the assurance of food and nutrient security have remained on the front burner influencing world policies over the years. Africa is the world's most food insecure continent, with relatively high and widespread inequalities, high rates of malnutrition and poverty, low rural incomes, and a worsening food trade balance (World Bank, 2007). Out of the 39 currently food insecure countries in the world, 31 are in Africa. More than 243 million people constituting about $27.4 \%$ (almost four times that of any other region in the world) of the continent's population suffer from severe food insecurity (FAO, 2018). The situation is more worrisome in sub-Saharan Africa where the prevalence of undernourishment $(\mathrm{PoU})$ is highest, affecting an alarming $22.7 \%$ of the population with an increase of almost three percentage points between 2014 and 2016. Ironically, the majority of the poor and hungry are farm families who rely on agriculture for livelihood (FAO, 2019).
In Nigeria, farming has not sufficiently assured sustainable livelihood for the rural populace because of reasons such as the low use of innovation and poor commercialisation of the agricultural sector. The Nigerian agricultural sectoris driven by millions of small-scale resource-poor farmers who continue to rely on crude implements and substandard methods with consequences for yield and production levels (Manyong et al., 2005). Nigeria, however, depends largely on the aggregate of the individual contribution of these farmers for local consumption (Daramola et al., 2007). In addition, with small and often fragmented farmlands, farm expansion is difficult. The level of commercialisation of most crops is therefore low as farmers' harvests are at times just about adequate to feed their households. Worse hit are some indigenous crops which have been relegated to accommodate other crops which farmers believe to either hold more economic value or to be easier to cultivate. One of such crops is cocoyam which is gradually becoming neglected and underutilised in Nigeria. 
Cocoyam is a tuber crop used mainly for human food. It is reported to have originated from Asia, and about 40 species are grown in West Africa (Asumugha and Mbanasor, 2002). Nigeria is the world's largest producer of cocoyam and is creditedwith about $37 \%$ of the total world output (NRCRI, 2009). From 0.73 million metric tons in 1990, cocoyam production in Nigeria rose to 3.89 million metric tons in 2000 (Ojiako et al., 2007) and further by $30.30 \%$ to 5.068 million metric tons in 2007 (FAO, 2007). Cocoyam is ranked third in importance after cassava and yam among the root and tubers crops cultivated in Nigeria (FAO, 2005; NBS, 2006). It is lower in starch, and higher in protein content when compared with other root crops which makes it ideal for the consumer on low starch diets. It has high medicinal properties and is also readily digestible than other tubers (Duru and Uma, 2002). The leaves of the plant are a rich source of folic acid, riboflavin, vitamin $\mathrm{A}$ and $\mathrm{C}$, calcium and phosphorus minerals and vitamins essential for healthy living (Duru and Uma, 2002). The leaves are consumed as vegetables because they are rich in protein and vitamins while the roots are rich in carbohydrates and minerals. The corms and cormels are eaten boiled, baked, and tubers are sometimes ground to producea paste for use in soups and stews. Another characteristic of cocoyam is that it is easy to intercrop. This is particularly important to farmers as mixed cropping is prominent among farmers in Nigeria due to the small size of their land holdings.

Given the importance and benefit of cocoyam, its production has not been givencommensurate attention. Okoye et al. (2008) blamed this on its poor acceptability among the high-income groups for both consumption and others purposes. The growing neglect for the crop will not only deprive households (especially rural) of the inherent nutritional benefits; it will also rob farming households of income derivable from its cultivation on a commercial scale. Awareness is the first stage of adoption and use. It is therefore important to investigate the level of awareness of the various uses/benefits of cocoyam. The attitude of farmers towards the commercialisation of cocoyam is of importance as this is likely to influence their decision to cultivate cocoyam. It is also possible that farmers face certain constraints that may hinder them from going into the cultivation of cocoyam on a commercial scale. An understanding of such challenges and their level of severity will assist policymakers in mitigating them and also in creating an enabling environment for thecommercialisation of the crop. Finally, socioeconomic characteristics of individuals such as age, educational and economic status have been reported to influence their perception and attitude (Omotesho et al., 2015) hence the need to investigate the determinants of farmers' attitude to the commercialization of the crop. The study therefore assessed the potentials for the commercialisation of cocoyam in Oyun Local Government Area of Kwara State. The specific objectives of the study were to (i) describe the socio-economic characteristics of farmers in the study area, (ii) examine the level of awareness on the uses of cocoyam among farmers, (iii) assess the level of cultivation of cocoyam in the study area, (iv) assess the attitude of farmers towards the commercialisation of cocoyam, and (v) identify the constraints to the commercialisation of cocoyam.

\section{Hypothesis}

The hypothesis of the study was stated in the null form, $\mathbf{H O}_{1}$ : socio-economic characteristics of farmers do not affect their attitude towards the commercialisation of cocoyam.

\section{MATERIALS AND METHODS Study Area}

The study was carried out in Oyun Local Government Area (LGA) of Kwara State, Nigeria, with its headquarters in the town of Ilemona. The LGA is located in the North-Central geopolitical zone of the country. It lies between latitudes $7^{0} 45^{\prime} \mathrm{N}$ and $9^{\circ} 30^{\prime} \mathrm{N}$ and longitudes $2^{0} 30^{\prime} \mathrm{E}$ and $6^{0} 25^{\prime} \mathrm{E}$. It has a total land area of $476 \mathrm{~km}^{2}$, with a population of about 142,888 people (NPC, 2006). Oyun LGA is primarily agrarian with a great expanse of arable land and fertile soils. Oyun LGA is noted for the cultivation of root crops in Kwara State. Other crops cultivated in the area include rice, cassava, cocoyam, yam, maize, sorghum, cowpeas, groundnut, melon, okra, pepper, and leafy vegetables. The 11 districts that make up the LGA (Oyun, Erinle-north, Erinlesouth, Igosun, Ikotun, Ilemona, Ipee, Irra, Ojoku, Inaja, and Ahogbada) are mainly rural communities with only little peri-urban sites. With the great expanse of arable land and fertile soil that support the cultivation of root crops, Oyun LGA has the potential to harness the opportunities in the commercialization of cocoyam. This will not only improve the livelihood of the farmers but improve the economy of the study area.

\section{Sampling Procedure and Sample Size}

The population for the study was made up of all farmers who grow cocoyam in Oyun LGA of Kwara State, Nigeria. A two-stage simple random sampling technique was used to select respondents for the study. In the first stage, half of the 11 wards in the LGA were randomly selected. The six selected wards were Ikotun, Irra, Ilemona, Igosun, Ipe, and Erinle-South. A sampling frame of 308 farmers was drawn from the selected communities with the help of the community leaders and the Agricultural Development Project extension agents in the LGA. The second stage was the random selection of $50 \%$ of the total number of farmers listed in each ward. A total of 154 respondents were interviewed. However, only 150 responses were found analyzable giving a response rate of $97 \%$. 


\section{Data Collection and Analytical Techniques}

The instrument for data collection was interview schedule. The results of the objectives of the study were analysed and presented using frequency distribution, percentages, and means. The Multiple Regression Analysis (Ordinary Least Square, OLS) was used to identify the determinants of farmers' attitude towards the commercialisation of cocoyam. The equation for the model was specified as follows;

$Y=\beta_{0}+\beta_{1} X_{1}+\beta_{2} X_{2}+\beta_{3} X_{3}+\ldots . .+\beta_{6} X_{6}+\beta_{7} D_{1}+e$

where $\beta_{0}$ is intercept, $\beta_{1}$ to $\beta_{8}$ are coefficients, $Y$ is attitude towards the commercialisation of cocoyam (measured using a four-point Likert-type scale). A set of statements which depicts farmers' attitude towards the commercialisation of cocoyam was drawn, and respondents were required to indicate the degree to which they agreed or disagreed. The scale was graduated as follows:

Strongly Disagree $=(1)$, Disagree $=(2)$, Agree $=(3)$, and Strongly Agree $=(4)$.

The scores were aggregated and converted to means for individual respondents. The mean scores were adopted as a measure of each respondent's positive attitude towards commercialisation of cocoyam. For ease of discussion, a benchmark was introduced to categorise the farmers' level of attitude whereby $<2.00=$ Poor, 2.00-3.00 = Fair, and $>3.00=$ Good. Then $X_{1}$ is age (in years), $X_{2}$ is highest level of education (number of years of schooling), $\mathrm{X}_{3}$ is average annual farm income (amount in $\mathrm{N}$ ), $\mathrm{X}_{4}$ is farming experience (years), $\mathrm{X}_{5}$ is farm size (acres), $\mathrm{X}_{6}$ is household size (number of people feeding from the same pot), $X_{7}$ is frequency of extension contact (number of contact in the immediate past six months period of the study), $\mathrm{D}_{1}$ is $\operatorname{sex}(1=$ male, $0=$ otherwise $), \mathrm{e}=$ error term.

Level of awareness of the uses of cocoyam was measured as a dummy variable. Various uses of cocoyam were listed, and respondents were required to indicate whether or not they were aware of the uses of cocoyam. The scale was graduated as; Not Aware $=0$, Aware $=1$. Percentages were calculated for each of the uses of cocoyam. The average score on the presented useswas taken as a measure of respondents' level of awareness of the uses of cocoyam. Constraints to commercialization of cocoyam was measured using four-point Likert-type scale. A list of possible constraints was drawn, and respondents were required to rate their level of severity on a scale of 1 to 4 as follows; Not a constraint $=1$, Not severe $=2$, Severe $=3$, Very severe $=4$. Scores were aggregated and converted to means for each of the listed constraints. The mean scores were adopted for the ranking of the constraints in order of severity.

\section{RESULTS AND DISCUSSION}

Socio-Economic Characteristics of Farmers

Table 1 shows that majority $(80.7 \%)$ of the farmers were above 45 years of age. Their mean age was 53.9 years. This result shows that the cultivation of cocoyam was done mostly by older farmers whose productivity might be declining as a result of deterioration in physical strength to carry out rigorous farming activities. This finding is consistent with those of Nwaru (2004) and Okoye (2014) who reported an aged population of cocoyam farmers. Most of the farmers (84\%) were male with only $16 \%$ female farmers. This shows a higher involvement of male farmers in cocoyam production in the area. The same was reported by Adepoju and Awodunmuyila (2008) who stated a high level of male involvement in farming because of the energy requirements in the cultivation. Also, $98.7 \%$ of the farmers were married while only $1.3 \%$ were either single or divorced. Though most of the respondents $(78.7 \%)$ had formal education, very few $(2.7 \%)$ had tertiary level of education. The high level of educational attainment is expected to make farmers more receptive to improved farming techniques and innovations (Okoye et al., 2004). Farming was the primary occupation of all $(100 \%)$ the respondents as also reported by Ifeanyi-Obi et al. (2017). The average farm size and year of farming experience were 4.3 acres and 21.8 years, respectively. Thi shows that majority of the respondents had adequate experience needed for cocoyam cultivation. Emodi et al. (2014) similarly reported that cultivation of root and tuber crops is an age-long profession among rural farmers. The mean frequency of extension contact (three times within a six-month period) is an indication of a low level of extension visit. Increased frequency of extension agent visits is an opportunity to transfer skill, knowledge, and information which could facilitate the cultivation of cocoyam.

\section{Awareness of the Uses of Cocoyam}

Table 2 shows the respondents' level of awareness on the uses of cocoyam. The respondents knew of the various uses of cocoyam including the use of its leaves for wrapping purposes $(100 \%)$, as food $(99.3 \%)$, as raw material in making flour $(97.3 \%)$, medicinal purposes $(93.3 \%)$ and its use in mulching (79.3\%). With an average level of awareness of $73.54 \%$, the level of awareness of the respondents was high. This could be as a result of their age as well as their appreciable number of years of farming experience. However, very few were aware that cocoyam could be used for confectioneries (35.3\%), as a thickener for baking $(27.3 \%)$ and spices and food flavour $(14.7 \%)$. This finding is understandable given the rural nature of the study area and the fact that confectioneries were not common in the area. Onyeka (2014) reported a high level of awareness of the uses of cocoyam among rural farmers. 
Table 1: Socio-economic characteristics of respondents

\begin{tabular}{|c|c|c|c|c|}
\hline Variables & $\begin{array}{l}\text { Freq- } \\
\text { uency }\end{array}$ & $\begin{array}{l}\text { Percent- } \\
\text { ages }\end{array}$ & Mean & SD \\
\hline Age (in years) & 1 & & & \\
\hline$\leq 35$ & 24 & 0.7 & & 7.95 \\
\hline $36-45$ & 54 & 16.0 & 53.9 & \\
\hline $46-55$ & 67 & 36.0 & & \\
\hline $56-65$ & 4 & 44.7 & & \\
\hline$\geq 66$ & & 2.7 & & \\
\hline \multicolumn{5}{|l|}{ Sex } \\
\hline Male & 126 & 84.0 & & \\
\hline Female & 24 & 16.0 & & \\
\hline \multicolumn{5}{|l|}{ Marital status } \\
\hline Married & 148 & 98.7 & & \\
\hline Otherwise & 2 & 1.3 & & \\
\hline \multicolumn{5}{|l|}{ Level of education } \\
\hline No formal education & 29 & 19.3 & & \\
\hline Quranic education & 3 & 2.0 & & \\
\hline Primary education & 57 & 38.0 & & \\
\hline Secondary education & 57 & 38.0 & & \\
\hline Tertiary education & 4 & 2.7 & & \\
\hline Primary occupation & 150 & & & \\
\hline Crop farming & 0 & 100.0 & & \\
\hline Otherwise & 145 & 0 & & \\
\hline Annual farm income & 2 & 96.7 & & \\
\hline$\leq 500,000$ & 3 & 1.3 & & \\
\hline $500,001-100,000,000$ & & 2.0 & 250,5 & \\
\hline$\geq 100,000,000$ & & & 13.3 & \\
\hline \multicolumn{5}{|l|}{ Farming experience } \\
\hline$\leq 10$ & 27 & 18 & & \\
\hline $11-20$ & 44 & 29.3 & 21.8 & 8.8 \\
\hline $21-30$ & 55 & 36.7 & & \\
\hline$\geq 31$ & 24 & 16.0 & & \\
\hline \multicolumn{5}{|l|}{ Farm Size } \\
\hline$\leq 5$ & 118 & 78.7 & & \\
\hline $6-15$ & 25 & 16.7 & 4.3 & 4.6 \\
\hline $16-25$ & 7 & 4.7 & & \\
\hline \multicolumn{5}{|l|}{ Mode of Land } \\
\hline Acquisition & 92 & 61.3 & & \\
\hline Inherited & 34 & 22.7 & & \\
\hline Leased & 16 & 10.7 & & \\
\hline Purchased & 8 & 53 & & \\
\hline Rent & 54 & 36.0 & & \\
\hline Household Size & 68 & 45.3 & & \\
\hline$\leq 5$ & 21 & 14.0 & & \\
\hline $6-10$ & 7 & 4.7 & & 3.6 \\
\hline $11-15$ & & 51.3 & & \\
\hline$\geq 16$ & 77 & 43.3 & & \\
\hline Extension & 65 & 4.0 & & \\
\hline Contact (Past six & 6 & 1.3 & 7.9 & \\
\hline months) & 2 & & & 1.9 \\
\hline \multicolumn{5}{|l|}{$\leq 2$} \\
\hline \multicolumn{5}{|l|}{$3-6$} \\
\hline $7-10$ & & & 3.2 & \\
\hline$\geq 11$ & & & & \\
\hline
\end{tabular}

Level of Cocoyam Cultivation in the Study Area Table 3 shows that $97.3 \%$ of the respondents cultivated cocoyam on a subsistence level while only $2.7 \%$ were involved in commercial production. This implies that cocoyam is another tuber crop used mainly for human food. It is commonly grown amongst small scale farmers who operate within the subsistence economy. Results also show that $98.7 \%$ of the respondents cultivate cocoyam annually. In addition, $22.7 \%$ of the respondents planted less than 100 a year while $71.3 \%$ of the respondents planted between 100 and 300 cormels. Very few $(2.7 \%)$ of the respondents planted between 301 and 500 cormels. This result confirms the low level of cultivation of the crop in the study area.

\section{Attitude of Farmers towards Commercialization of Cocoyam}

The results in Table 4 show the attitude of farmers towards the commercialisation of cocoyam. The farmers agreed that the commercialisation of cocoyam could increase farmers' livelihood status (mean score $=2.71)$ as well as assist in poverty alleviation (mean score $=2.65$ ). Farmers also agreed that cocoyam is an insurance crop that could help to meet unforeseen circumstances (mean score $=2.63$ ) and combat food insecurity in Nigeria (mean score $=2.25$ ). This agrees with the findings of Acheampong et al. (2014) who opined that cocoyam production was mostly used for human consumption and as an important food security crop in times of failure or shortage of other crops. Respondents, however, did not agreed that the commercialisation of cocoyam could be a source of foreign exchange earnings for the country (mean score $=2.05$ ).

The respondents also did not agreed that there was always a ready market for cocoyam (mean score $=2.01$ ) and that it was better to focus on the commercialisation of cocoyam than on other tuber crops (mean score $=1.99$ ). The respondents also did not agree that the industrial utilisation of cocoyam was high (mean score $=1.99$ ) and that the production ofcocoyam was profitable compared to other tuber crops (mean score $=1.57$ ). In addition, farmers did not agree that exporting cocoyam was achievable because there was no international demand for the crop (mean score $=1.48$ ).

Table 2: Respondents'awareness of the uses of cocoyam

\begin{tabular}{lll}
\hline Uses * & Aware F (\%) & Not aware F (\%) \\
\hline The broad leaves are equally used for wrapping purposes, e.g., kolanut, bitter-cola, etc. & $150(100)$ & $0(0)$ \\
Cocoyam can be fried into chip & $149(99.3)$ & $1(0.7)$ \\
Cormels are peeled, cut into necessary pieces then, boil and eat; or boil to pound like pounded yam & $148(98.7)$ & $2(1.3)$ \\
Cocoyam can be processed into flours & $146(97.3)$ & $4(2.7)$ \\
Cocoyam is used for medicinal purposes & $140(93.3)$ & $10(6.7)$ \\
Cocoyam is used for cooking local soups & $135(90)$ & $15(10)$ \\
Cocoyam leaves can be used for mulching purposes & $119(79.3)$ & $31(20.7)$ \\
Dried cormelsare used for confectionary & $53(35.3)$ & $97(64.7)$ \\
Cocoyam is used as a thickener in baking & $41(27.3)$ & $109(72.7)$ \\
The leaves and flowers are used as spice to garnish and flavour food & $22(14.7)$ & $128(85.3)$ \\
\hline
\end{tabular}

Source: Field survey, 2018. *multiple responses. Mean Score $(73.52 \%)$ 
Table 3: Distribution of respondents according to their levels of cultivation of cocoyam

\begin{tabular}{|c|c|c|c|c|}
\hline Variables & Frequency & Percentages & Mean & SD \\
\hline \multicolumn{5}{|l|}{ Level of involvement in cocoyam production; } \\
\hline subsistence (for household consumption) & 146 & 97.3 & & \\
\hline commercial (for market and sales) & 4 & 2.7 & & \\
\hline Frequency of cultivation; annual & 148 & 98.7 & & \\
\hline once in two years & 2 & 1.3 & & \\
\hline Land allocated to cocoyam cultivation (acre) $;<1$ & 30 & 20.7 & & \\
\hline $1-3$ & 117 & 78.0 & & \\
\hline$>3$ & 2 & 1.3 & 1.9 & 0.62 \\
\hline Proportion of produce sold; $\leq 25 \%$ & 102 & 68.0 & & \\
\hline$>25 \%$ & 48 & 32.0 & & \\
\hline Cormel planted per year; $<100$ & 34 & 22.7 & & \\
\hline $100-300$ & 107 & 71.3 & & \\
\hline $301-500$ & 4 & 2.7 & 180.2 & 131.7 \\
\hline$>500$ & 5 & 3.4 & & \\
\hline
\end{tabular}

Table 4: Attitude of farmers towards commercialization of cocoyam

\begin{tabular}{|c|c|c|c|c|c|c|}
\hline Attitudinal statements & $\begin{array}{l}\text { SA F } \\
(\%)\end{array}$ & $\begin{array}{l}\text { A F } \\
(\%)\end{array}$ & $\begin{array}{l}\text { D F } \\
(\%)\end{array}$ & $\begin{array}{l}\text { SD F } \\
(\%)\end{array}$ & Score & MS \\
\hline Cocoyam commercialization can increase farmers' livelihood & $10(6.7)$ & $92(61.3)$ & $43(28.7)$ & $5(3.3)$ & 407 & 2.71 \\
\hline $\begin{array}{l}\text { Poverty alleviation of farmers can be achieved through } \\
\text { the commercialisation of cocoyam }\end{array}$ & $1(0.7)$ & $99(66)$ & $46(30.7)$ & $4(2.7)$ & 397 & 2.65 \\
\hline Cocoyam is an insurance crop to meet unforeseen circumstances & $10(6.7)$ & $78(52)$ & $58(38.7)$ & $4(2.7)$ & 394 & 2.63 \\
\hline Cocoyam is a food for majority of urban populace & $0(0)$ & $81(54)$ & $64(42.7)$ & $5(3.3)$ & 376 & 2.51 \\
\hline Cocoyam commercialization can help combat food insecurity & $0(0)$ & $37(24.7)$ & $113(75.3)$ & $0(0)$ & 337 & 2.25 \\
\hline $\begin{array}{l}\text { Cocoyam commercialization can be a source of } \\
\text { foreign earnings for the country }\end{array}$ & $2(1.3)$ & $4(2.7)$ & $143(95.3)$ & $1(0.7)$ & 307 & 2.05 \\
\hline There is always a ready market for cocoyam & $1(0.7)$ & $5(3.3)$ & $138(92)$ & $6(4)$ & 301 & 2.01 \\
\hline $\begin{array}{l}\text { It is better to focus on the commercialisation of } \\
\text { cocoyam than other tuber crops }\end{array}$ & $1(0.7)$ & $3(2)$ & $139(92.7)$ & $7(4.7)$ & 298 & 1.99 \\
\hline The industrial utilization of cocoyam is high & $0(0)$ & $2(1.3)$ & $144(96)$ & $4(2.7)$ & 298 & 1.99 \\
\hline Sales of cocoyam are profitable compared to other tuber crops & $1(0.7)$ & $12(8)$ & $59(39.3)$ & $78(52)$ & 236 & 1.57 \\
\hline $\begin{array}{l}\text { Exporting cocoyam is achievable because there is an } \\
\text { international demand for cocoyam }\end{array}$ & $1(0.7)$ & $4(2.7)$ & $61(40.7)$ & $84(56)$ & 222 & 1.48 \\
\hline
\end{tabular}

SD, Strongly Disagreed; D, Disagreed; A, Agreed; SA, Strongly Agreed); Source: Field Survey, 2018

Distribution of Respondents by their Attitude Towards the Commercialization of Cocoyam Results presented in Table 5 shows the distribution of respondents by their attitude towards the commercialisation of cocoyam. The findings reveal that $2.7 \%$ of the farmers had a poorattitude towards the commercialisation of the crop while the majority $(96 \%)$ had a fair attitude towards it. Only $1.3 \%$ of the farmers had a goodattitude towards the commercialisation of cocoyam. The mean attitude score was 2.38, and this implies that the general attitude towards the commercialisation of cocoyam in the study area was only fair. This could be as a result of their perception that other tuber crops were better and more profitable. Thiscorroborates the findings of Agwu et al. (2012).

Table 5: Distribution of respondents based on their attitude towards the commercialisation of cocoyam

\begin{tabular}{llll}
\hline Attitude & Frequency & Percentage & Mean \\
\hline Poor $(<2.00)$ & 4 & 2.7 & \\
Fair $(2.00-3.00)$ & 144 & 96.00 & 2.38 \\
Good $(>3.00)$ & 2 & 1.3 & \\
\hline
\end{tabular}

Source: Field Survey, 2018.

\section{Constraints to Cocoyam Commercialization}

Table 6 shows the most severe constraint was the high susceptibility of cocoyam to pests and diseases. (mean score $=3.13)$. This implies that that pests and diseases were the major factors hindering the commercialisation of cocoyam in the study area. Okoye (2014) and Opata and Adeosun (2016) similarly reported that the low level of research and innovation that could provide disease resistant and high yielding varieties were perhaps responsible for the inefficient cocoyam cultivation and commercialisation in Nigeria. High demand of other tuber crops such as yam and cassava (mean score = 3.09 ), poor attitude of farmers towards the commercialisation of cocoyam (mean score $=2.65$ ) and low knowledge of the uses of cocoyam (mean score $=2.56$ ) were rated $2^{\text {nd }}, 3^{\text {rd }}$ and $4^{\text {th }}$, respectively. Poor post-harvest handling was identified as the least constraint to the commercialisation of cocoyam.

\section{The Result of Tested Hypothesis}

H01: Socio-economic characteristics of farmers do not affect their attitude toward the commercialization of cocoyam. The multiple regression model with eight predictors produced $\mathrm{R}^{2}=.408, \mathrm{~F}(8,152)=$ 
2.262, $P<0.01$. This implies that the four significant regressors in the model explained $40.8 \%$ of the variations observed in attitude towards the commercialisation of cocoyam among the respondents. As shown in Table 7 , age $(\beta=-0.008)$, level of education $(\beta=-0.046)$, household size $(\beta=$ $-0.012)$ and frequency of extension contact $(\beta=$ 0.018) significantly affected farmers' attitude towards the commercialisation of cocoyam. The positive influence of frequency of extension contact on farmers' attitude implies that the more extension contacts the farmers have, the better their attitude towards commercialisation of cocoyam. Ele et al. (2013) similarly reported that increase in extension contact would increase farmers' positive attitude towards commercialisation in agriculture. On the contrary, farmers' positive attitude towards the commercialisation of cocoyam declined with age. This implies that the younger farmers'attitudes were more positive. The older the farmers become, the more negative their attitude is. The fact that younger farmers are likely to be more physically fit, economically-driven and open to new ideas could all play a part in this finding. At $p<0.10$, the educational level of the respondents also influenced their attitude. The negative coefficient implies that the more educated the farmers were, the poorer their attitude towards the commercialisation of the crop. It is possible that educated farmers would rather focus on crops that were more commonly consumed and demanded in urban markets. Though it is argued that education enables an individual to make independent choices and to act by the decisions as well as increase the tendency to cooperate with other people and participate in group activities, it is also possible that education could increase the chances of the household head earning non-farm income. This would reduce the farmers' dependence on cocoyam commercialisation for survival (Martey et al., 2012). Also, positive attitude toward the commercialisation of cocoyam declined with increase in household size. It could be that large household sizes discouraged commercial orientation due to increasing household domestic consumption needs. Similar findings were reported by Enete and Igbokwe (2009) and Gebremedhin and Jaleta (2010). However, annual farm income, sex, farm size, marital status was not significant in predicting farmers' attitude towards the commercialisation of cocoyam.

Table 6: Constraints to commercialization of cocoyam

\begin{tabular}{|c|c|c|c|c|c|c|c|}
\hline Constraints & VS F $(\%)$ & S F (\%) & NS F (\%) & $\mathrm{NC} \mathrm{F}(\%)$ & Score & MS & Rank \\
\hline High susceptibility of cocoyam to pests and diseases & $79(52.7)$ & $12(8)$ & $58(38.7)$ & $1(0.7)$ & 469 & 3.13 & $1^{\text {st }}$ \\
\hline $\begin{array}{l}\text { High demand of other tuber crops such } \\
\text { as yam and cassava }\end{array}$ & $72(48)$ & $20(13.3)$ & $57(38)$ & $1(0.7)$ & 463 & 3.09 & $2^{\text {nd }}$ \\
\hline $\begin{array}{l}\text { Poor attitude of farmers towards the } \\
\text { commercialization of cocoyam }\end{array}$ & $2(1.3)$ & $98(65.3)$ & $46(30.7)$ & $4(2.7)$ & 398 & 2.65 & $3^{\text {rd }}$ \\
\hline Low knowledge of the uses of cocoyam & $4(2.7)$ & $77(51.3)$ & $68(45.3)$ & $1(0.7)$ & 384 & 2.56 & $4^{\text {th }}$ \\
\hline Inadequate knowledge on cocoyam production & $5(3.3)$ & $80(53.3)$ & $58(38.7)$ & $7(4.7)$ & 383 & 2.55 & $5^{\text {th }}$ \\
\hline Poor awareness of nutritional and economic importance & $8(5.3)$ & $66(44)$ & $73(48.7)$ & $3(2)$ & 379 & 2.53 & $6^{\text {th }}$ \\
\hline High susceptibility of planting materials to decay & $5(3.3)$ & $46(30.7)$ & $95(63.3)$ & $4(2.7)$ & 352 & 2.35 & $7^{\text {th }}$ \\
\hline Unavailability of market for cocoyam & $5(3.3)$ & $43(28.7)$ & $99(66)$ & $3(2)$ & 350 & 2.33 & $8^{\text {th }}$ \\
\hline Lack of improved varieties of cocoyam & $1(0.7)$ & $29(19.3)$ & $110(73.3)$ & $10(6.7)$ & 321 & 2.14 & $13^{\text {th }}$ \\
\hline Lack of technology for planting, processing and storage & $7(4.7)$ & $51(34)$ & $43(28)$ & $49(32.7)$ & 316 & 2.11 & $14^{\text {th }}$ \\
\hline Lack of extension workers interest in the crop & $8(5.3)$ & $5(3.3)$ & $131(87.3)$ & $6(4)$ & 315 & 2.10 & $15^{\text {th }}$ \\
\hline Lack of access to research outputs on cocoyam & $3(2)$ & $9(6)$ & $135(90)$ & $3(2)$ & 312 & 2.08 & $16^{\text {th }}$ \\
\hline $\begin{array}{l}\text { Low research on the crop when compared } \\
\text { with other tuber crops }\end{array}$ & $3(2)$ & $5(3.3)$ & $135(90)$ & $7(4.7)$ & 304 & 2.03 & $17^{\text {th }}$ \\
\hline Lack of training on cocoyam production and utilization & $4(2.7)$ & $6(4)$ & $126(84)$ & $14(9.3)$ & 300 & 2.00 & $18^{\text {th }}$ \\
\hline Unavailability of improved planting materials & $6(4)$ & $32(21.3)$ & $34(22.7)$ & $78(52)$ & 266 & 1.77 & $19^{\text {th }}$ \\
\hline Inadequate international funding of projects on cocoyam & $5(3.3)$ & $5(3.3)$ & $63(42)$ & $77(51.3)$ & 238 & 1.59 & $20^{\text {th }}$ \\
\hline Poor post-harvesting techniques & $6(4)$ & $15(10)$ & $0(0)$ & $129(86)$ & 198 & 1.32 & $21^{\mathrm{st}}$ \\
\hline
\end{tabular}

Source: Field Survey, 2018

Table 7: Determinants of farmers' attitude towards the commercialization of cocoyam

\begin{tabular}{lllll}
\hline Socio-economic characteristics & Beta & Std. Error & t-value & Sig \\
\hline Constant & 3.018 & 0.159 & 18.971 & 0.000 \\
Age & $-0.008^{* * *}$ & 0.002 & -3.190 & 0.002 \\
Sex & -0.046 & 0.046 & -0.994 & 0.322 \\
Level of Education & $-0.046^{* *}$ & 0.018 & -2.592 & 0.011 \\
Annual farm income & 0.006 & 0.000 & 0.168 & 0.867 \\
Farming experience & -0.003 & 0.002 & -1.380 & 0.170 \\
Farm size & -0.003 & 0.004 & -0.869 & 0.386 \\
Household size & $-0.012^{* *}$ & 0.005 & -2.265 & 0.025 \\
Extension contact & $0.018^{* *}$ & 0.009 & 1.912 & 0.058 \\
\hline Source: Fid Survey
\end{tabular}

Source: Field Survey, 2018. $\mathrm{R}^{2}=0.408$ 


\section{CONCLUSIONS/RECOMMENDATIONS}

Based on the high level of awareness of the uses of cocoyam and the fair positive attitude towards the commercialization of the crop, the study concluded that there are huge potentials for commercialization of cocoyam in Oyun LGA of Kwara State. Based on the findings and conclusion of the study, the following recommendations are put forward:

- National Root Crops Research Institute and other Agricultural Research Institutes should explore the breading of pest and disease resistant as well as high yielding varieties of cocoyam.

- Extension agents should facilitate links between farmers and markets for cocoyam.

- Ministry of Agriculture and stakeholders in nutrition and dietetics should create awareness (in urban areas) on the benefits and uses of cocoyam as a close substitute to yam and other tubers in human nutrition.

- Extension personnel should improve their contact with the farmers and create awareness of the benefits of the commercialisation of the crop.

\section{REFERENCES}

Acheampong P., Osei-adu J., Amengo E. and Sagoe R. (2014). Cocoyam value chain and benchmark study in Ghana. Report to the West Africa Agricultural Productivity Programme. Available online: https://www.researchgate.net/publication/274953291

Adepoju A.A. and Awodunmuyila D.J. (2008). Economics of cocoyam production and marketing in Ekiti East Local Government Area, Ekiti State, Nigeria. Res. J. Appl. Sci., 3 (2), 95-98

Agwu N.M., Anyanwu C.I. and Mendie E.I. (2012). Socio-economic determinants of commercialization among small holder farmers in Abia State, Nigeria. Greener J. Agric. Sci., 2 (8), 392-397

Asumugha G.N. and Mbanasor E.N.A. (2002). Cost effectiveness of farm gate cocoyam processing in agriculture; a basic poverty eradication and conflict resolution strategy. Federal University of Technology, Owerri (FUTO) Imo State, Nigeria, pp. 94-97

Daramola A., Ehui S., Ukeje E. and McIntire J. (2007). Agricultural export potential. In: Collier P.C. and Pattillo C. (Eds.), Economic Policy Options for a Prosperous Nigeria, Palgrave Macmillan

Duru C.C. and Uma N.U. (2002). Post-harvest spoilage of cormels of Xanthosoma sagiltifolia (L) schoott. Biosci. Res. Comm., 14, 277-283

Ele I.E., Omini G.E., Adinya D.I. (2013). Assessing the extent of commercialization of smallholding farming households in Cross River State, Nigeria. IOSR J. Agric. Vet. Sci., 4 (2), 49-55

Emodi A.I., Obiora C.J. and Okere J. (2014). Socioeconomic analysis of cocoyam farmers in Ngor Okpala Local Government Area of Imo State, Nigeria. $J$. Sustainable Dev. Afr., 16 (2), 91-101

Enete A.A. and Igbokwe E.M. (2009). Cassava market participation decision of households in Africa. Tropicultura, 27 (3), 129-136

FAO (2005). FAOSTAT Database. Food and Agricultural Organisation (FAO). Available online at: http:/apps.fao.org/default.htm

FAO (2007). FAOSTAT. Statistic Division of the Food and Agriculture Organisation (FAO). http://faostat.fao.org/site/562/desktopdefault.aspx page 10-567 accessed July 03, 2008 Data Base result
FAO (2018). Crop prospects and food situation. Food and Agricultural Organisation (FAO) Quarterly Global Report 2. http://www.fao.org/giews/reports/crop-prospects/en/ FAO (2019). Putting family farmers first to eradicate hunger. Food and Agricultural Organisation (FAO). http://www.fao.org/news/story/en/item/260535/icode/

Gebremedhin G. and Jaleta M. (2010). Commercialisation of smallholders: Does market orientation translate into market participation? Improving Productivity and Market Success (IPMS) of Ethiopian Farmers' Project. Working Paper 22. ILRI, Nairobi, Kenya

Ifeanyi-Obi C.C., Togun A.O., Lamboll R., Adesope O.M. and Arokoyu S.B. (2017). Challenges faced by cocoyam farmers in adapting to climate change in Southeast, Nigeria. Climate Risk Manage, 17, 155-164

Manyong V.M., Ikpi A., Olayemi J.K. (2005). Agriculture in Nigeria: Identifying opportunities for increased commercialisation and investment. IITA, Ibadan, Nigeria

Martey E., Al-Hassan R.M. and Kuwornu J.K.M. (2012). Commercialisation of smallholder agriculture in Ghana: A tobit regression analysis. Afr. J. Agric. Res., 7(14), 2131-2141

NBS (2006). Annual Abstract of Statistics. National Bureau of Statistics, Federal Republic of Nigeria, Abuja

NPC (2006). National Population Commission (NPC), Abuja, Nigeria

NRCRI (2009). Munich Personal RePEc Archives (MPRA). National Root Crops Research Institute, (NRCRI), Umudike, Nigeria

Nwaru J.C. (2004). Rural Credit Markets and Resources Use in Arable Crop Production in Imo State of Nigeria. Unpublished Ph.D. Thesis, Michael Okpara University of Agriculture, Umudike

Ojiako I.A., Asumugha G.N., Ezedinma C. and Uzokwe N.E. (2007). Analysis of production trends in the major root and tuber crops in Nigeria, 1961-2005. Res. Crops, 8 (2), 371-380

Okoye B.C., Asumugha G.N., Okezie C.A., Tanko L. and Onyenweaku C.E. (2008). Econometric assessment of the trend in cocoyam production in Nigeria, 1960/612003/2006. Agric. J., 3 (2), 99-101

Okoye B.C., Okorji E.C. and Asumugha G.N. (2004). Outlook of production economics of paddy rice under resource constraints in Ebonyi State. Proceedings of the 38th Annual Conference of The Agricultural Society of Nigeria $(A S N)$ held at Nasarawa Polytechnic, Lafia, Nasarawa State, 17-21 October, pp. $337-342$

Okoye F.U. (2014). Gender and Resource Use Efficiency In Cocoyam Production in Anambra State, Nigeria. MSc Dissertation, Department of Agricultural Economics, University of Nigeria, Nsukka. pp. 52

Omotesho K.F., Olabode D.A., Animashaun J.O. and Ogunlade I. (2015). Knowledge and attitude of agriculture students towards commercialization of date palm in University of Ilorin, Nigeria. J. Res. For., Wildlife Environ., 7 (2), 91-102

Onyeka J. (2014). Status of cocoyam (Colocasia esculenta and Xanthosoma spp.) in West and Central Africa: production, household importance and the threat from leaf blight. Lima (Peru): CGIAR Research Program on Roots, Tubers and Bananas (RTB). Available online at: www.rtb.cgiar.org

Opata P.I. and Adeosun K.P. (2016). Performance of cocoyam market chain in South East Nigeria. Europ. J. Business Manage, 8 (3), 192-203

World Bank (2007). World Development Report: Agriculture for Development. World Bank Publications: Washington, DC 